\title{
Development of a complete ELISA using Salmonella lipopolysaccharides of various serogroups allowing to detect all infected pigs
}

\author{
Karine ProuX*, Catherine Houdayer, Florence Humbert, \\ Roland CARIOLET, Valérie Rose, Eric Eveno, François MADEC
}

AFSSA Ploufragan, BP 53, Zoopôle Beaucemaine, 22440 Ploufragan, France

(Received 27 January 2000; accepted 16 May 2000)

\begin{abstract}
Although poultry is recognized as the major source of food-poisoning caused by Salmonella, pork also contributes to human infections. This study was therefore undertaken in order to develop a reliable serological method for the evaluation of the Salmonella status of piglets. A complete ELISA was performed using lipopolysaccharides of Salmonella Typhimurium, Anatum, Hadar and Infantis because these serovars were representative of the serogroups isolated from 30 contaminated fattening farms. $S$. Enteritidis was also added because of its importance in human infection and to include the O : 9 antigen. This method potentially detects 100\% of infected pigs. A significant correlation was found between this serological method and the bacteriological data from mesenteric lymph nodes $(p=0.01)$. In addition, both sensitivity and specificity were high $(97 \%$ and $94 \%$ respectively). The ELISA test was therefore used in a cross-sectional study on 4 farms to evaluate when pigs became contaminated: seropositive pigs were only found for the 20 week old finishing pigs. The antibody response to Salmonella in piglets was also investigated: maternal antibodies persisted until 7 weeks of age and post-Salmonella contamination seroconversion was detected from 8 weeks of age onwards.
\end{abstract}

\section{ELISA / Salmonella / pig / epidemiology}

Résumé - Mise au point d'une méthode ELISA complète basée sur des lipopolysaccharides de plusieurs sérogroupes permettant de détecter tous les porcs infectés par des salmonelles. Bien que la volaille soit la principale source d'intoxication alimentaire par les salmonelles, le porc contribue aussi à la contamination humaine. Cette étude a été menée pour mettre au point une technique sérologique permettant d'évaluer le statut infectieux des porcelets vis-à-vis des salmonelles. Une technique ELISA dite complète a été élaborée avec des lipopolysaccharides de Salmonella Typhimurium, Anatum, Hadar et Infantis, sérovars représentatifs des sérogroupes isolés dans 30 élevages engraisseurs contaminés. $S$. Enteritidis a été ajoutée en raison de son importance dans les infections humaines et afin d'inclure l'antigène $\mathrm{O}:$ 9. Cette méthode permet de dépister potentiellement $100 \%$

* Correspondence and reprints

Tel.: (33) 2960162 77; fax: (33) 2960162 63; e-mail: k.proux@ploufragan.afssa.fr 
des porcs infectés par des salmonelles. La corrélation était significative entre cette technique sérologique et les tests bactériologiques sur les ganglions mésentériques $(p=0.01)$ et la sensibilité ainsi que la spécificité étaient élevées (respectivement de $97 \%$ et $94 \%$ ). Aussi cet ELISA a été utilisé pour préciser la période de contamination des porcs dans une étude transversale dans 4 élevages : des sérologies positives ont été recensées uniquement sur les porcs de 20 semaines. La présence d'anticorps chez les porcelets a été étudiée : la persistance des anticorps maternels a été observée jusqu'à 7 semaines et une séroconversion a été détectée à partir de 8 semaines indiquant une contamination probable par des salmonelles.

ELISA / Salmonella / porc / épidémiologie

\section{INTRODUCTION}

Although it has been well established that poultry is a major source of food-poisoning caused by Salmonella [12], pork also contributes to human infections [13, 19]. ELISA is a valuable tool to detect infected pigs [14] because it is inexpensive and rapid compared with the bacteriological method. It may be automated and used for the rapid screening of high numbers of pig herds. It has already been largely used for monitoring in Denmark, Germany and the USA where serum or muscle fluid have been tested [6, $16,18]$. In a preliminary study, an indirect ELISA based on purified lipopolysaccharide antigens from $S$. Typhimurium only, was compared to the bacteriological method [9]. Many serovars induce infections and even if one is of minor importance now, in the future it may become a major threat to human or animal health. As a consequence it is a conventional view that all Salmonella are potential pathogens [4]. Moreover each country needs to have its own method which is adapted to its Salmonella status. This is the reason why it was necessary to develop an ELISA test detecting antibodies against all the serovars found on French pig farms.

Therefore the aim of our study was to use this method called the complete ELISA method to find all infected pigs in a population and to evaluate risk factors of contamination, to reduce the Salmonella spread among pigs on the farm and finally to ensure food safety. In addition this method was used to investigate the Salmonella status of piglets: the period when Salmonella-contamination occurred and maternal antibody persistence.

\section{MATERIALS AND METHODS}

\subsection{Animals and samples}

\subsubsection{Development of the complete ELISA}

Twenty-three farms were selected because of their contamination by Salmonella. Twenty pigs from each farm were bacteriologically and serologically checked at slaughter for Salmonella: approximately $10 \mathrm{~g}$ of faeces were extracted from the rectum after it had been singed. In addition, one mesenteric lymph node from the small intestine and the sera obtained just after bleeding were tested. The faeces from groups of 5 pigs were pooled, but lymph nodes and sera were processed individually.

\subsubsection{Antibody detection in a pig population}

In a cross-sectional study in each of the 4 selected farms, blood samples were obtained on the same day from 50 animals that comprised ten pregnant sows, ten farrowing sows, ten 8-week old pigs, ten 14week old growing pigs and ten 20 -week old finishing pigs. 


\subsubsection{Antibody detection in piglets}

On one farm, sera were obtained randomly from five pregnant sows, five farrowing sows and different groups of five pigs (at 1, 4, 7, 10, 13, 19 and 25 weeks of age) on the same day. On another farm sera from four sows and their progeny (litters of ten piglets) from 2 to 11 weeks of age were tested in order to investigate the transmission of maternal antibodies and to evaluate seroconversion induced by the contamination with the $S$. Typhimurium strain present on this farm.

\subsubsection{Calibration of the ELISA}

In order to test the sensitivity of our ELISA test, one experimental study was performed on five specific pathogen free pigs (S.P.F.). At 12 weeks of age, two pigs were inoculated orally with $10^{10} \mathrm{CFU}$ $S$. Typhimurium, two were inoculated with $10^{8} \mathrm{CFU}$ and one was kept in contact with the latter two pigs. The sera were collected thirteen times periodically (all 5 or 6 days) from 14 to 23 weeks of age.

Eighty-four pigs from two conventional herds ( 28 pigs from one herd and 56 from the second) were tested bacteriologically to check whether they were Salmonella-free before their sera was used to test specificity and to evaluate the positive cut-off of our ELISA. Environmental swabs (14 from the first farm and 21 from the second farm) and faeces from all pigs were collected on the 2 farms whereas mesenteric lymph nodes and sera were obtained from each pig in the slaughterhouse.

\subsection{Salmonella strains}

S. Hadar, Infantis and Anatum strains used to prepare the lipopolysaccharide antigens and $S$. Typhimurium used for inoculation of S.P.F. pigs were isolated on the field from finishing pigs. Serovars were confirmed by the French Agency for Food
Safety (AFSSA, Paris, France) which is the Salmonella reference laboratory for animal isolates.

\subsection{Extraction of LPS}

The LPS antigens from $S$. Anatum, Hadar and Infantis were produced in our laboratory by a modification of method of Hancock and Poxton [7]. The Salmonella Anatum, Hadar and Infantis strains were isolated from pigs, cultured in $50 \mathrm{~mL}$ of peptone buffered water overnight and centrifuged for $30 \mathrm{~min}$ at $10000 \times g$. The pellet was then suspended to a concentration of approximately $5 \% \mathrm{w} / \mathrm{v}$ in ultrapure water. The bacterial suspension was prewarmed to $67{ }^{\circ} \mathrm{C}$ for $15 \mathrm{~min}$ in a water bath. One volume of a $90 \%$ v/v phenol solution heated to $45^{\circ} \mathrm{C}$ was added to an equal volume of the bacterial suspension in polypropylene tubes. After gentle shaking at $67^{\circ} \mathrm{C}$ for $15 \mathrm{~min}$, the tubes were cooled in ice until phase separation occurred. The tubes were centrifuged at $10000 \times g$ for $15 \mathrm{~min}$. The upper phase containing the LPS was transferred to washed dialysis tubes and dialysed against running tap water for $18 \mathrm{~h}$.

\subsection{ELISA}

The serological method initially based only on $S$. Typhimurium lipopolysaccharide (LPS) antigens (Sigma Diagnostics, St Louis, USA) was designated as the simple ELISA [9]. The complete ELISA was prepared with various LPS: commercial antigens for $S$. Typhimurium and $S$. Enteritidis (Sigma Diagnostics, St Louis USA) and antigens produced as described above.

Commercial antigens were prediluted in ultrapure water $\left(1 \mathrm{mg} \cdot \mathrm{mL}^{-1}\right)$. For the simple ELISA, in which the LPS from $S$. Typhimurium were used as the antigens, $9 \mu \mathrm{L}$ of the previous solution were added to $6 \mathrm{~mL}$ carbonate buffer $\mathrm{pH} 9.8$ per plate (final concentration $1.5 \mu \mathrm{g} \cdot \mathrm{mL}^{-1}$ coating 
buffer). For the complete ELISA, all the LPS were mixed, $3 \mu \mathrm{L}$ of each of the five LPS were added to $6 \mathrm{~mL}$ coating buffer. A control without antigen made of the various diluents present in the preparation of the LPS was also prepared (dilution for $6 \mathrm{~mL}$ coating buffer: $9 \mu \mathrm{L}$ in the simple ELISA and $15 \mu \mathrm{L}$ for the complete ELISA, corresponding to the total volume of the LPS antigens). All the following steps were then the same for the simple or the complete ELISA.

Half of the microwells were coated with $100 \mu \mathrm{L}$ per well of the positive antigen composed of LPS, and the other half with the control without antigen, and then incubated at $37{ }^{\circ} \mathrm{C}$ for $2 \mathrm{~h}$ (Costar, Cambridge, USA). The plates were washed three times between each stage. They were blocked for $30 \mathrm{~min}$ at $37{ }^{\circ} \mathrm{C}$ with $100 \mu \mathrm{L}$ PBS-Tween containing $5 \%$ dried milk powder and $0.02 \% \mathrm{NaN}_{3}$ per well. Sera were diluted 1:400 in PBS-Tween containing $2 \%$ dried milk powder and $10 \%$ foetal calf sera and $100 \mu \mathrm{L}$ was added to positive and negative antigen coated wells and incubated for $45 \mathrm{~min}$ at $37^{\circ} \mathrm{C}$. Peroxidase conjugated rabbit anti-pig IgG antibody (Dako, Glostrup, Denmark), $100 \mu \mathrm{L}$ diluted 1:1000 in PBS-Tween solution, was added to each well. After $1 \mathrm{~h}$ incubation at $37{ }^{\circ} \mathrm{C}$ followed by washing, $100 \mu \mathrm{L}$ orthophenylene diamine solution containing one $45 \mathrm{mg}$ tablet in $50 \mathrm{~mL}$ citrate buffer $\mathrm{pH} 5$ and $66 \mu \mathrm{L} \mathrm{H}_{2} \mathrm{O}_{2}$ (Sigma Diagnostics, St Louis, USA) was used as the substrate. After $30 \mathrm{~min}$ at room temperature, the reaction was stopped with $100 \mu \mathrm{L} 0.5 \mathrm{M}$ sulphuric acid per well (Prolabo, Fontenay-sous-Bois, France). Coloration was read with a Dynatech MR 5000 spectrophotometer with 490 and $630 \mathrm{~nm}$ filters used respectively as the test and reference filter. Positive and negative control sera were provided by the Danish Veterinary Laboratory (Copenhagen, Denmark) and were repeated twice on each plate in order to obtain the mean values which were named the OD negative control and OD positive control.
To eliminate background OD caused by reaction with the diluents, a corrected optical density (OD) equal to the difference between the optical density with the positive and the control without antigen was calculated for each sample.

The background OD with the negative sera was corrected by the following calculation of R equal to: (OD sample - OD negative control)/(OD positive control - OD negative control). The calibrated optical density (COD) was then calculated as: $\mathrm{R} \times$ (mean OD positive control / OD positive control on the plate). The mean value was established on 50 different plates for the positive control and was equal to 1 .

For the calibration of the ELISA, sensitivity was tested on 65 sera collected from S.P.F. pigs (two of which were inoculated with $10^{10} \mathrm{CFU} S$. Typhimurium, two were inoculated with $10^{8}$ CFU $S$. Typhimurium and one was non-inoculated but infected by the latter two pigs reared in the same room).

Specificity and positive cut-off were evaluated on 84 conventional finishing pigs from two Salmonella-free herds. The positive cutoff corresponded to the mean COD + 1.99 standard deviation $(p=0.975)$. With these calculations, the positive cut-off was 0.4 .

\subsection{Bacteriological analysis}

Samples were diluted in buffered peptone water (Armor Equip. Scientific Lab., Combourg, France) (1:5 to 1:10 dilution $\mathrm{w} / \mathrm{v}$ ) and were incubated for 16 to $20 \mathrm{~h}$ at $37^{\circ} \mathrm{C}$. The enrichment step used semi-solid Rappaport Vassiliadis medium (Biokar Diagnostic, Beauvais, France) incubated at $41.5^{\circ} \mathrm{C}$ and presumptive positive results indicated by migration were sub-cultured onto Rambach agar (Merck, Nogent sur Marne, France). Two crimson characteristic isolated colonies were confirmed biochemically and serotyped using appropriate polyand monovalent typing sera (Sanofi-Diagnostic Pasteur, Marnes La Coquette, France). 


\subsection{Statistical analysis}

Serological results of sera with simple and complete ELISA and the bacteriological results of faeces and lymph nodes were compared using the Wilcoxon test (used for paired samples). The different correlation coefficients were calculated between both serological methods and between serological and bacteriological results.

\section{RESULTS}

\subsection{Development of a complete ELISA}

The different serovars isolated from finishing pigs on 30 selected farms are pre- sented in Table I. As a consequence, the complete ELISA was performed to potentially detect the main serovars in each of the 4 Salmonella groups (B, E1, C1 and C2), which represented all the serogroups obtained on the farms. The 600 sera from these 30 farms of finishing pigs were tested with the simple ELISA (based only on $S$. Typhimurium LPS) and with the complete ELISA (Tab. II). The difference between the results of the 2 assays was not significant (coefficient of the Wilcoxon test $=64.9 \%$ ) and the correlation was highly significant (correlation coefficient $r=0.634$, $p=0.001$ ). But the percentage of positive sera was slightly higher with the complete ELISA (mean positive $\%=41.3$ ) than with the simple ELISA (mean positive $\%=38.9$ ).

Table I. Main Salmonella serovars isolated on finishing pigs from 30 naturally infected farms.

\begin{tabular}{lcccc}
\hline & & & \multicolumn{2}{c}{ Number of serovars $(\%)$} \\
\cline { 4 - 5 } Serovar & Somatic antigens (O) & Group & Lymph nodes & Faeces \\
\hline Typhimurium & $1,4,5,12$ & $\mathrm{~B}$ & $10(29.4)$ & $10(26.3)$ \\
Derby & $1,4,5,12$ & $\mathrm{~B}$ & $9(26.5)$ & $10(26.3)$ \\
Bredeney & $1,4,12,27$ & $\mathrm{~B}$ & $6(17.7)$ & $5(13.2)$ \\
Brandenburg & $1,4,12$ & $\mathrm{~B}$ & $/$ & $3(7.9)$ \\
Heidelberg & $1,4,5,12$ & $\mathrm{~B}$ & $/$ & $1(2.6)$ \\
Anatum & 3,10 & E1 & $5(14.7)$ & $1(2.6)$ \\
London & 3,10 & E1 & $/$ & $2(5.3)$ \\
Infantis & 6,7 & $\mathrm{C} 1$ & $2(5.9)$ & $4(10.6)$ \\
Tennessee & $6,7,14$ & $\mathrm{C} 1$ & $1(2.9)$ & $/$ \\
Ohio & $6,7,14$ & $\mathrm{C} 1$ & $/$ & $1(2.6)$ \\
Hadar & 6,8 & $\mathrm{C} 2$ & $1(2.9)$ & $/$ \\
Goldcoast & 6,8 & $\mathrm{C} 2$ & $/$ & $1(2.6)$
\end{tabular}

Table II. Positive samples (\%) tested from the 30 naturally infected farms.

\begin{tabular}{lccccc}
\hline & \multicolumn{2}{c}{ Serology } & & \multicolumn{2}{c}{ Bacteriology } \\
\cline { 2 - 3 } \cline { 5 - 6 } & $\begin{array}{c}\text { Simple } \\
\text { ELISA }^{\mathrm{a}}\end{array}$ & $\begin{array}{c}\text { Complete } \\
\text { ELISA }^{\mathrm{b}}\end{array}$ & & $\begin{array}{c}\text { Mesenteric } \\
\text { Lymph Nodes }\end{array}$ & Faeces \\
\hline Minimum & 0 & 0 & & 0 & 0 \\
Maximum & 100 & 94 & & 100 & 63.3 \\
Mean & 38.9 & 41.3 & & 39.7 & 34.6 \\
Standard deviation & 31.2 & 30.1 & & 31.6 & 75.0 \\
Median & 30.5 & 40.5 & & 27.5 & 0 \\
\hline
\end{tabular}

a $S$. Typhimurium LPS based ELISA.

b $S$. Typhimurium, Anatum, Infantis, Hadar and Enteritidis LPS based ELISA. 
A comparison of serological and bacteriological data showed a small but significant correlation between the complete ELISA and the bacteriological analysis of lymph nodes (correlation coefficient $r=0.4490$, $p=0.01$ ). Only one herd found positive by bacteriological analysis of mesenteric lymph nodes ( 3 positive results out of 20 nodes tested) was serologically negative with the complete ELISA although the results could

Table III. Specificity and sensitivity of the complete ELISA obtained from 65 sera sampled on experimentally contaminated pigs and 84 Salmonella free conventional finishing pigs.

\begin{tabular}{lccc}
\hline Serology & \multicolumn{2}{c}{ Salmonella status } & Total \\
\cline { 2 - 3 } & $\begin{array}{c}\text { Experimental } \\
\text { contamination }\end{array}$ & $\begin{array}{c}\text { Conventional } \\
\text { Salmonella free }\end{array}$ \\
\hline+ & $63(\mathrm{~A})$ & $5(\mathrm{~B})$ & 68 \\
- & $2(\mathrm{C})$ & $79(\mathrm{D})$ & 81 \\
Total & $65(\mathrm{~A}+\mathrm{C})$ & $84(\mathrm{~B}+\mathrm{D})$ & 149 \\
\hline
\end{tabular}

Sensitivity : $A /(A+C)=97 \%$.

Specificity : D / $(B+D)=94 \%$. be interpreted as weakly positive. On the contrary, two seropositive herds (first herd: $10 \%$ positive; second herd: $90 \%$ positive) were negative bacteriologically according to the culture of the lymph nodes. When a comparison was made between the serological results and bacteriological results from faecal samples, the correlation was not significant $(r=0.165)$.

Concerning the calibration of the complete ELISA, sensitivity was $97 \%$ and specificity was $94 \%$ (Tab. III).

\subsection{Detection of seropositive pigs}

In a cross-sectional study on 4 farms, all the groups of 8-week old pigs and 14-week old pigs were seronegative. Older pigs (20 weeks) were seropositive in 3 herds (including herd 4 which was weakly positive) while at the same sampling time, high seroprevalence and high COD values were observed in pregnant and farrowing sows (Tab. IV).

Table IV. Seropositive pigs (\%) and mean corrected optical density (MCOD) in herds of 4 selected farms for 5 different groups of pigs.

\begin{tabular}{|c|c|c|c|c|c|c|c|c|}
\hline \multirow{3}{*}{$\begin{array}{l}\text { Animals } \\
\left(\mathrm{n}^{\circ}\right)\end{array}$} & \multicolumn{8}{|c|}{ Herd } \\
\hline & \multicolumn{2}{|r|}{1} & \multicolumn{2}{|c|}{2} & \multicolumn{2}{|c|}{3} & \multicolumn{2}{|c|}{4} \\
\hline & $\%^{a}$ & $\begin{array}{c}\operatorname{MCOD}^{\mathbf{b}} \\
\quad(\mathrm{SD})\end{array}$ & $\%$ & $\begin{array}{l}\text { MCOD } \\
\text { (SD) }\end{array}$ & $\%$ & $\begin{array}{l}\text { MCOD } \\
\text { (SD) }\end{array}$ & $\%$ & $\begin{array}{c}\text { MCOD } \\
\text { (SD) }\end{array}$ \\
\hline $\begin{array}{l}\text { Farrowing sows } \\
\text { (10) }\end{array}$ & 62 & $\begin{array}{c}0.422 \\
(0.194)\end{array}$ & 40 & $\begin{array}{c}0.306 \\
(0.108)\end{array}$ & 100 & $\begin{array}{c}0.522 \\
(0.199)\end{array}$ & 40 & $\begin{array}{c}0.464 \\
(0.325)\end{array}$ \\
\hline $\begin{array}{l}\text { Pregnant sows } \\
\text { (10) }\end{array}$ & 92 & $\begin{array}{c}0.467 \\
(0.199)\end{array}$ & 55 & $\begin{array}{c}0.287 \\
(0.107)\end{array}$ & 80 & $\begin{array}{c}0.462 \\
(0.136)\end{array}$ & 90 & $\begin{array}{c}0.824 \\
(0.504)\end{array}$ \\
\hline $\begin{array}{l}8 \text { week old } \\
\text { (10) }\end{array}$ & 0 & $\begin{array}{l}0.073 \\
0.034\end{array}$ & 0 & $\begin{array}{l}0.038 \\
0.018\end{array}$ & 0 & $\begin{array}{l}0.035 \\
0.015\end{array}$ & 0 & $\begin{array}{l}0.022 \\
0.035\end{array}$ \\
\hline $\begin{array}{l}14 \text { week old } \\
\text { (10) }\end{array}$ & 0 & $\begin{array}{c}0.087 \\
(0.033)\end{array}$ & 0 & $\begin{array}{c}0.039 \\
(0.027)\end{array}$ & 0 & $\begin{array}{c}0.061 \\
(0.047)\end{array}$ & 0 & $\begin{array}{c}0.063 \\
(0.053)\end{array}$ \\
\hline $\begin{array}{l}20 \text { week old } \\
\text { (10) }\end{array}$ & 60 & $\begin{array}{c}0.546 \\
(0.445)\end{array}$ & 50 & $\begin{array}{c}0.494 \\
(0.448)\end{array}$ & 0 & $\begin{array}{c}0.082 \\
(0.037)\end{array}$ & 10 & $\begin{array}{c}0.113 \\
(0.102)\end{array}$ \\
\hline
\end{tabular}

a $\%$ of seropositive pigs.

${ }^{\mathrm{b}}$ Mean corrected optical density (SD). 


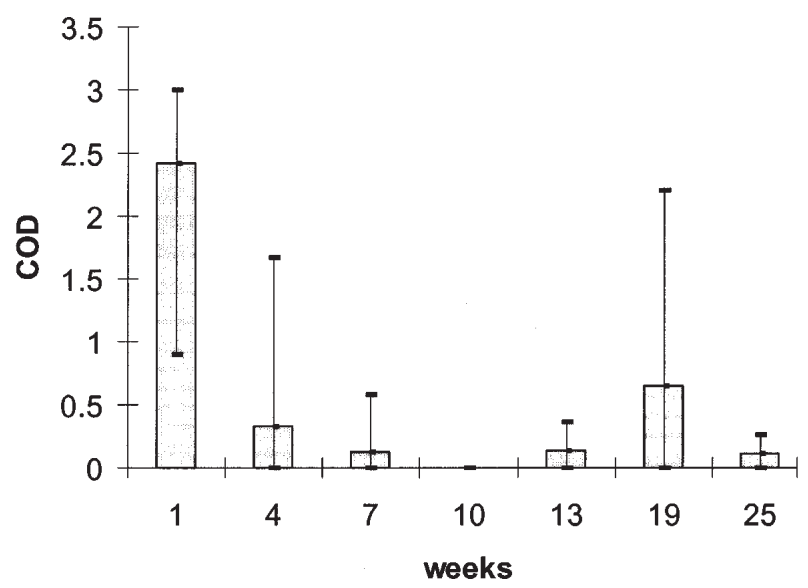

Figure 1. ELISA values (mean $\pm \mathrm{SD}$ ) of different groups of 5 piglets.

\subsection{Presence of antibodies in piglets}

In pigs aged from 1 week to 25 weeks and randomly tested, mean COD was high at 1 week of age (mean COD $=2.4$ ) and $100 \%$ of the pigs were seropositive. All the pigs were negative at 10 weeks of age. The COD then increased until 19 weeks of age (mean COD $=0.643$ ) when $40 \%$ of the pigs were seropositive. In the group examined at 25 weeks of age, the COD values were lower than those in the group tested at 19 weeks of age (Fig. 1). Furthermore, at the same time on this farm, 5 pregnant and 5 farrowing sows showed a mean COD as high as 2.312 (standard deviation $=0.862$ ) and $90 \%$ seropositivity.

On the second farm, transmission of antibodies from sows to their own piglets are presented in Figure 2. It appeared that the first group of ten piglets issued from the seronegative sow A $(\mathrm{COD}=0.221)$ could be used as the control because the mean COD remained negative from 2 to 11 weeks of age. On the contrary, the 10 piglets whose dam B had a really high COD value (1.134), were all highly seropositive with a mean COD of 0.883 (standard deviation $=0.265$ ); only one of them remained seropositive until 5 weeks of age $(\mathrm{COD}=0.452)$. For the other
2 litters, the piglets were seronegative at 3 weeks of age although the sows were seropositive $(\mathrm{COD}=0.980$ and 0.781 for sow $\mathrm{C}$ and $\mathrm{D}$ ). Then the antibody levels increased in two piglets, one in the litter of sow $\mathrm{C}$ and one in the litter of sow D. The COD values became seropositive at 8 weeks of age in one litter and 11 weeks of age in the other, possibly indicating that there was contamination by the $S$. Typhimurium strain isolated on this farm.

\section{DISCUSSION}

The complete ELISA allowed us to potentially detect all prevalent serovars isolated on French pig farms belonging to the $\mathrm{B}, \mathrm{E} 1, \mathrm{C} 1$, or $\mathrm{C} 2$ groups, because it was based on the somatic antigens $(\mathrm{O}: 1,3,5,6$, $7,8,9,10,12)$. In comparison, theoretically 95\% of Salmonella serovars occurring in Danish pigs are detectable with the mixELISA based on $S$. Typhimurium $(\mathrm{O}: 1,4$, $5,12)$ and Choleraesuis antigens $(O: 6,7)$ developed by Nielsen et al. [14] in Denmark [1]. In our study, the percentage of positive sera obtained in the 30 infected farms was just slightly higher with the complete ELISA than with the simple ELISA. This may be 
Piglets from sow $A$

$(C O D=0.221) n=10$

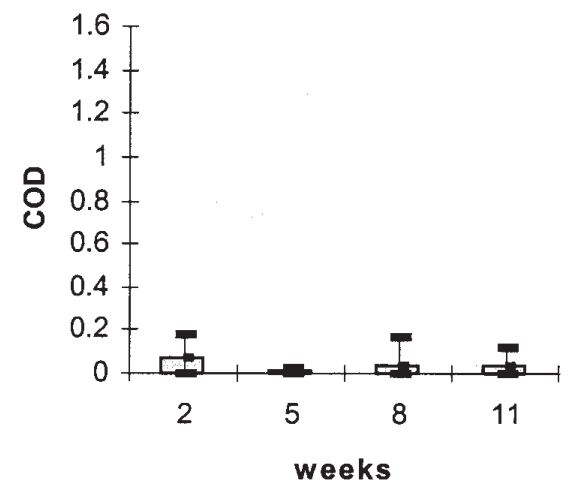

Piglet from sow $C$ $(C O D=0.980) n=1$

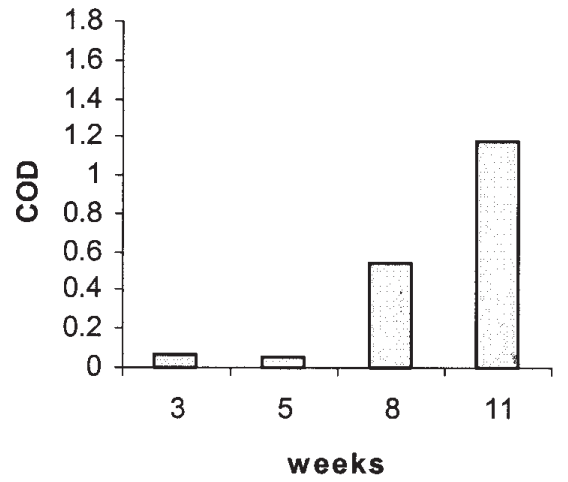

Piglets from sow $B$

$(C O D=1.134) n=10$

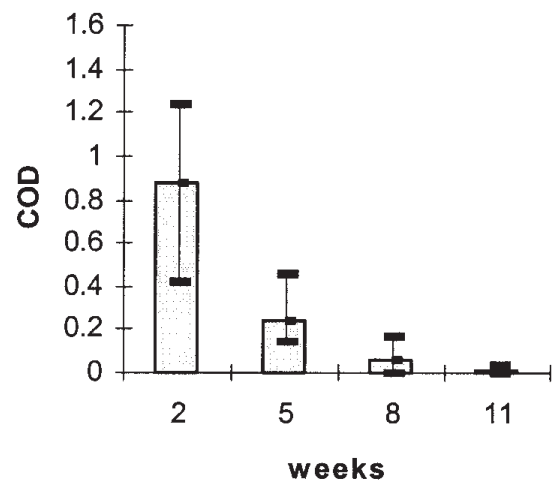

\section{Piglet from sow $D$ $(C O D=0.781) n=1$}

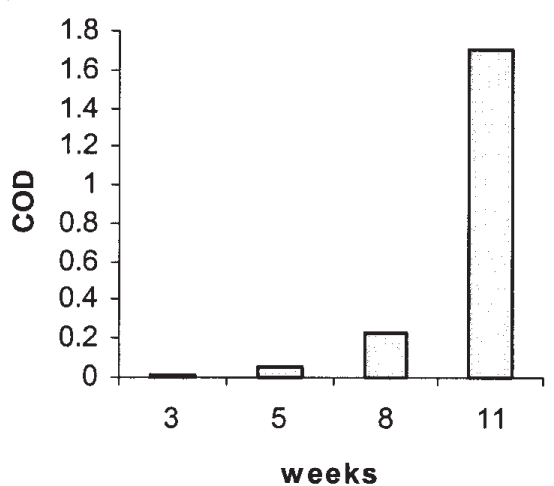

Figure 2. Antibody kinetics of piglets issued from 4 different sows at farrowing.

explained by the fact that most of the serovars belonged to the same group as $S$. Typhimurium and were detected by the simple ELISA because of their common antigens with this serovar. Moreover Salmonella strains have different recovery rates during isolation procedures and this implies that the presence of certain strains can be underestimated [20]. As a conse- quence, the farms may have been infected by different serovars and it is possible that Salmonella belonging to group B were present in the samples but that they were not isolated.

The complete ELISA has acceptable sensitivity and specificity, but other artificial inoculation experiments must be conducted 
to test whether false positive reactions may be induced when immunisation against other bacteria, belonging to the Enterobacteriaceae family that share common antigens with Salmonella, occurs. On the 30 selected farms, results from this complete ELISA and bacteriological findings from lymph nodes were correlated, with an acceptable risk of $1 \%$. Moreover the herd that was found to be positive by bacteriology on lymph nodes and negative with the complete ELISA was in fact weakly positive. A recent infection may explain this lack of correlation between the two methods; when the analyses were performed, Salmonella were invading the mesenteric nodes but antibodies were not yet detectable by serology. Further sera samples a few days later would have been necessary to prove this hypothesis. On the contrary, antibodies may persist a long time after the Salmonella have already been eliminated [8]. The results obtained with the complete ELISA were not correlated with the bacteriological results from the faeces. This may be easily explained by the intermittent excretion of Salmonella in the faeces and the poor sensitivity of one-time sampling of faeces to detect Salmonella $[10,11]$, but this sensitivity increases markedly with the weight of the faeces sampled [5].

According to our results, maternal antibodies were detectable in the sera of the progeny when the COD value of the sow was high (sow B). This was not totally in contradiction with the findings of Nielsen et al. [15] who found that at the herd level, seroprevalence in sows is a poor predictor of herd seroprevalence in fattening pigs; however in a particular herd with a high seroprevalence and high OD values in sows, they found a high seroprevalence in 3-week old pigs. Piglets of the 2 seropositive sows $\mathrm{C}$ and $\mathrm{D}$ were seronegative at 3 weeks of age but the results were not available at 2 weeks of age, and maternal antibodies may have been eliminated. Besides, porcine immunoglobulins $\mathrm{G}$ are not transmitted transplacentally but are delivered via the colostrum. In further studies it may be useful to evaluate the level of antibodies in the colostrum where they are 3 to 10 times more concentrated than in sow sera [17]. Maternal antibodies may passively protect piglets during the first weeks but these antibodies decrease after a few weeks. When these maternally derived antibodies decrease, piglets are no longer protected and environmental Salmonella may contaminate them. This contamination was revealed by the increase of the active immunisation at 8 weeks of age for piglets from sow $C$ and D and delayed to 13 weeks of age on the other farm. These results were almost equivalent to those reported by Nielsen et al. [15] who found that a few piglets seroconverted at 7 weeks of age while most seroconversions occurred later. However, the potential protection conferred by maternal antibodies has to be confirmed by an experimental challenge on piglets with high levels of maternal antibodies. First, these results may help evaluate the risks of vertical transmission of Salmonella from sows to piglets, but it needs to be proven that if sows present serologically high titres, they may also excrete more Salmonella and their piglets will be more exposed to environmental contamination. Secondly, antibodies were detected at 8 weeks of age indicating that pigs became contaminated 7 or 8 days earlier. In further studies, bacteriological analysis of environmental swabs and faecal samples from sows and their piglets have to be done in order to determine the origin of this contamination: vertical transmission related to the excretion of sows, horizontal transmission by contact with the other piglets when mixing lots of pigs, materials and housing or food. According to Dahl et al. [3], transmission of Salmonella from sows to offspring was of little importance in subclinically infected herds but this study was mainly based on serological results. Moreover according to Berends et al. [2], horizontal transmission by housing is of great importance as a risk factor when a given pen is contaminated. The current probability 
that further pens in the same location will get contaminated is about $90 \%$.

\section{ACKNOWLEDGEMENTS}

This work was supported by European funds in the Agricultural Orientation and Guarantee project concerning descriptive epidemiology of Salmonella in pig herds and development of an available method of screening. The authors are grateful to the staff for taking care of S.P.F. pigs.

\section{REFERENCES}

[1] Bager F., Emborg H.D., Sorensen L.L., Halgaard C., Jensen P.T., Control of Salmonella in Danish pork, Fleischwirtschaft 75-78 (1995) 10001001 .

[2] Berends B.R., Urlings H.A.P., Snijders J.M.A., van Knapen F., Identification and quantification of risk factors in animal management and transport regarding Salmonella spp. in pigs, Int. J. Food Microbiol. 30 (1996) 37-53.

[3] Dahl J., Wingstrand A., Baggesen D.L., Nielsen B., Elimination of Salmonella typhimurium infection by the strategic movement of pigs, Vet. Rec. 140 (1997) 679-681.

[4] Davies P.R., Funk J.A., Epidemiology and control of Salmonella in pork - some of the questions, Proceedings of the Third International Symposium on Epidemiology and Control of Salmonella in Pork, Washington, DC, USA, August 5-7, 1999, pp. 1-11.

[5] Funk J.A., Davies P.R., Nichols M.G., Evaluation of sample weight for the isolation of Salmonella spp. from swine feces, Proceedings of the Second International Symposium on Epidemiology and Control of Salmonella in Pork, Copenhagen, Denmark, August 20-22, 1997, pp. 97-99.

[6] Gray J.T., Fedorka-Cray P.J., Stabel T.J., Ackermann M.R., Influence of inoculation route on the carrier state of Salmonella choleraesuis in swine, Vet. Microbiol. 47 (1995) 43-59.

[7] Hancock I.C., Poxton I.R., Bacterial cell surface techniques, Wiley-Interscience publication, Great Britain, 1988.

[8] Hoorfar J., Wedderkopp A., Lind P., Comparison between persisting anti-lipopolysaccharide antibodies and culture at postmortem in Salmonella-infected cattle herds, Vet. Microbiol. 50 (1996) 81-94.

[9] Humbert F., Proux K., Bohnert M., Madec F., Looking for a reliable method to follow the Salmonella status of finishing pigs, Proceedings of the Second International Symposium on Epidemiology and Control of Salmonella in Pork, Copenhagen, Denmark, August 20-22, 1997 , pp. 129-131.

[10] Kampelmacher E.H., Guinee P.A.M., Hofstra K, Further studies of Salmonella in slaughterhouses and in normal slaughter pigs, Zentralbl. Veterinaermed. 10 (1963) 1-27.

[11] Larkin P.J., Hicks M., Diagnosis and treatment of chronic Salmonella typhimurium infection in sows, Vet. Rec. 81 (1967) 231-234.

[12] Louis M.E.S., Morse D.L., DeMelfi T.L., Guzewih J.J., Tauxe R.V., Blake P.A., The emergence of grade A eggs as major source of Salmonella enteritidis infections, J. Am. Vet. Med. Assoc. 259 (1988) 2103-2107.

[13] Maguire H.C.F., Codd A.A., Mackay V.E., Rowe B., Mitchell E., A large outbreak of human salmonellosis traced to a local pig farm, Epidemiol. Infect. 110 (1993) 239-246.

[14] Nielsen B., Baggesen D.L., Bager F., Haugegaard J., Lind P., The serological response to Salmonella serovars typhimurium and infantis in experimentally infected pigs. The time course followed with an indirect anti-LPS ELISA and bacteriological examinations, Vet. Microbiol. 47 (1995) 205-218.

[15] Nielsen J.P., Andreasen M., Carstensen B., Salmonella herd profiles established by serological testing, Proceedings of the Second International Symposium on Epidemiology and Control of Salmonella in Pork, Copenhagen, Denmark, August 20-22, 1997, pp. 110-113.

[16] Nielsen B. , Ekeroth L., Bager F., Lind P., Use of muscle fluid as a source of antibodies for serologic detection of Salmonella infection in slaughter pig herds, J. Vet. Diagn. Invest. 10 (1998) 158-163.

[17] Newby T.J., Stokes C.R., Bourne F.J., Immunological activities of milk, Vet. Immunol. Immunopathol. 3 (1982) 67-94.

[18] Protz D., Staak C., Steinbach G., Käsbohrer A., Helmuth R., Pilot study on the prevalence of Salmonella in slaugter pigs in germany: IV. Field experiences using the Danish serological method for detection, Proceedings of the Second International Symposium on Epidemiology and Control of Salmonella in Pork, Copenhagen, Denmark, August 20-22, 1997, pp. 251-253.

[19] Wegener H.C., Baggesen D.L., Investigation of an outbreak of human salmonellosis caused by Salmonella enterica spp. enterica serovar Infantis by pulsed field gel electrophoresis, Int. J. Food. Microbiol. 32 (1996) 125-131.

[20] van Winsen R.L., Swanenburg M., Snijders J.M.A., Urlings H.A.P., Recovery of Salmonella serotypes from swine faecal samples using ISO 6579, Proceedings of the Third International Symposium on Epidemiology and Control of Salmonella in Pork, Washington, DC, USA, August 5-7, 1999, pp. 90-91. 